\title{
The roles of innate and acquired immune responses on HTLV-I infection
}

\author{
Mari Kannagi ${ }^{1 *}$, Shuichi Kinpara ${ }^{1}$, Atsuhiko Hasegawa ${ }^{1}$, Ayako Takamori1, Yukiko Shimizu', Atae Utsunomiya ${ }^{2}$ \\ From 15th International Conference on Human Retroviruses: HTLV and Related Viruses \\ Leuven and Gembloux, Belgium. 5-8 June 2011
}

The level of HTLV-I expression is low in vivo. We found that recombinant interferon (IFN) $-\alpha$ and $\beta$ suppressed viral expression in HTLV-I-infected cells. Non-lymphoid stromal cells also suppressed HTLV-I expression through type-I IFNs. The suppression was reversible after isolation of infected cells from the source of IFNs, mimicking the status of viral expression in freshly isolated ATL cells which is rapidly induced in culture. Nevertheless, HTLV-I-infected individuals maintain acquired immune responses against HTLV-I such as antibodies and cytotoxic T lymphocytes (CTLs), indicating the presence of HTLV-I proteins in vivo. Analysis on Tax-specific CTLs revealed that they were activated in HAM/TSP but unresponsive in ATL patients. We found that a subpopulation of HTLV-I carriers at asymptomatic stage exhibited impaired Tax-specific T-cell response and elevated HTLV-I proviral load. This combination is a feature of ATL and likely to be an underlying risk of ATL. Collectively, HTLV-I is doubly controlled by acquired and innate immunity; HTLV-Ispecific CTLs eliminate infected cells, and IFNs suppress viral expression. Both would contribute the reduction of viral pathogenesis, while the efficiency of CTLs could be partial because of limited viral expression. An increase in viral expression would activate CTLs but also accelerate inflammation. When the viral expression is well-controlled, viral pathogenesis may not be apparent until infected cell clones with a malignant phenotype finally emerge, which may occur earlier without proper CTL responses. Diversity in innate and acquired immune responses among individuals might be important determinants of disease manifestation in HTLV-I infection.

\footnotetext{
* Correspondence: kann.impt@tmd.ac.jp

'Department of Immunotherapeutics, Tokyo Medical and Dental University, Graduate School, Tokyo, Japan

Full list of author information is available at the end of the article
}

\section{Author details}

${ }^{1}$ Department of Immunotherapeutics, Tokyo Medical and Dental University, Graduate School, Tokyo, Japan. 'Department of Hematology, Imamura Bunin Hospital, Kagoshima, Japan.

Published: 6 June 2011

doi:10.1186/1742-4690-8-S1-A100

Cite this article as: Kannagi et al:: The roles of innate and acquired immune responses on HTLV-I infection. Retrovirology 2011 8(Suppl 1): A100.
Submit your next manuscript to BioMed Central and take full advantage of:

- Convenient online submission

- Thorough peer review

- No space constraints or color figure charges

- Immediate publication on acceptance

- Inclusion in PubMed, CAS, Scopus and Google Scholar

- Research which is freely available for redistribution

Submit your manuscript at www.biomedcentral.com/submit

\section{() Biomed Central}

C Biomed Central

C 2011 Kannagi et al; licensee BioMed Central Ltd. This is an open access article distributed under the terms of the Creative Commons Attribution License (http://creativecommons.org/licenses/by/2.0), which permits unrestricted use, distribution, and reproduction in any medium, provided the original work is properly cited. 